\title{
Characterization of Plant Growth Promoting Rhizobial Isolates for Pigeon Pea (Cajanus cajan [L.] Mill sp)
}

\author{
B. A. Harshitha ${ }^{1 *}$, Geeta. Goudar ${ }^{2}$, P. U. Krishnaraj ${ }^{2}$ and R. V. Koti ${ }^{3}$ \\ ${ }^{1}$ Department of Agricultural Microbiology, College of Agriculture, Vijayapur, ${ }^{2}$ Department of \\ Agricultural Microbiology, College of Agriculture, Dharwad, ${ }^{3}$ Department of Crop \\ physiology, College of Agriculture, Dharwad, University of Agricultural Sciences, \\ Dharwad, Karnataka, India \\ *Corresponding author
}

\section{A B S T R A C T}

Ke y w o r d s
Rhizobium,
PGPR, IAA,
P-solubilization

Study was conducted to isolate and characterize Rhizobia from root nodules of pigeon pea from Vijayapur, Kalaburgi and Bagalkot districts of northern regions of Karnataka. Ten Rhizobial isolates and reference strain PPM35B were subjected for nodulation test. All the isolates showed positive result for nodulation. The number of nodules was ranging from 12 to 14.5 per plant. All these isolates were also subjected for functional characterization. The amount of IAA, GA production and ACC deaminase activity by different rhizobial isolates ranged from 16.60 to $22.85 \mu \mathrm{g} \mathrm{IAA} / \mathrm{ml}$ of broth, 11.00 to $14.43 \mu \mathrm{g} / 25 \mathrm{ml}$ of broth and 44.5 to $73.5 \mathrm{nmoles}$ of $\alpha$-ketobutyrate/mg/h of broth respectively. The diameter of $\mathrm{P}, \mathrm{Zn}$ and $\mathrm{Si}$ solubilization by the rhizobial isolates was ranged from 4.5 to $10.3 \mathrm{~mm}, 9.5$ to $20.5 \mathrm{~mm}$ and 5.5 to $6.5 \mathrm{~mm}$, respectively. These isolates were further subjected for morphological and biochemical characterization. All the isolates were found to be rod shaped and gram negative. All the isolates were positive for citrate utilization, catalase, urease, oxidase, acid and gas production tests whereas negative for Voges proskauer's and indole production test.

\section{Introduction}

Pigeon pea (Cajanus cajan [L.] Mill sp.), is the second most important kharif pulse crop grown in India after chickpea. In India, it is predominantly grown in rainfed conditions. It is used as a food, fodder and fuel wood. It maintains soil fertility through nitrogen fixation by its microsymbiont Rhizobium, as well as from the leaf fall and recycling of the nutrients.
One of the major problems that limit economically successful agricultural production in yield of pigeon pea worldwide is poor soil fertility. One of the way to correct this problem is addition of biofertilizers which improves soil fertility by supplying nutrients needed for optimum crop growth by fixing an atmospheric nitrogen, mineral solubilization etc., (Osman et al., 2011).

Biological nitrogen fixation (BNF) is a 
process by which $\mathrm{N}_{2}$ in the atmosphere is reduced into a biologically useful, combined form of Nitrogen to ammonia by living organisms (Giller, 2001). It is estimated that endosymbiotic biological nitrogen fixation globally represents approximately $90 \%$ of all the fixed nitrogen in the terrestrial environment. Mutualism between legumes and rhizobia is regarded as the most important biological mechanism for providing nitrogen to the leguminous plants as an alternate to the expensive nitrogenous fertilizers, also it can make agriculture more productive and sustainable with its eco-friendly nature (Kantar et al., 2003). The activity of Rhizobium inhabiting root nodules often results fixing large amounts of nitrogen which ranges from 25 to $201 \mathrm{~kg} \mathrm{~N} / \mathrm{ha}$ in grain legumes (Dakora and Kenya, 1997).

In addition to biological nitrogen fixation by rhizobia it also promote plant growth by its plant growth promoting traits through mechanisms that are independent of biological nitrogen fixation (Ahemad and Kibret, 2013, Peix et al., 2001, Alikhani and Yakhchali, 2009), which includes stimulating plant growth directly either by synthesizing plant hormones such as indole-3-acetic acid (IAA), Gibberellic acid (GA) or by promoting nutritional processes such as mineral solublization (Phosphate solubilisation) and production of siderophore, HCN. Through its antagonistic activity it also stimulate plant growth indirectly by protecting the plant against fungal pathogens (Hemissi et al., 2011). When legume plants grow in low nutrient media (Dakora et al., 2002), rhizobia use these excluded compounds to enhance mineral nutrition by production of organic acid to solubilize phosphorous (P) and manganese $(\mathrm{Mn})$ and iron $(\mathrm{Fe})$ is mobilized by production of Siderophores (Carson et al., 2000, Richardson, 2001). IAA released from rhizobia massively proliferate root hair growth and thus enhance the root's absorptive capacity and nutrient uptake in legume system (Yanni et al., 2001). Hence the present study was undertaken to isolate and screen rhizobia for their plant growth promoting activity in addition to their excellent symbiotic effectiveness.

\section{Materials and Methods}

\section{Isolation of Rhizobial isolates}

Root nodule samples of pigeon pea were obtained from Vijayapur, Kalaburgi and Bagalkot districts of northern regions of Karnataka. The root nodule samples from 60 days old pigeon pea plants were collected and placed in sterile polythene bags and brought to laboratory for isolation of Rhizobia.

Fresh root nodules of pigeon pea plants were collected and sterilized with $70 \%$ ethanol for 4-5 min and $0.1 \% \mathrm{HgCl}_{2}$ for $1 \mathrm{~min}$. Nodules were then rinsed, crushed in sterile distilled water, streaked on yeast extract manitol agar (YEMA) plates and incubated at $29 \pm 2^{\circ} \mathrm{C}$ for 3 days (Bhattachary and chandra, 2013). At the end of incubation period, the rhizobial colonies with white, translucent and elevated were selected. These Rhizobium colonies were purified and used for the study.

\section{Assessment of nodulation under laboratory condition}

The Rhizobium like isolates obtained from root nodules of pigeon pea were tested for their ability to nodulate the host plant using small plastic cups filled with sterilized soil. About 4-5 seeds of pigeon pea were sown in each cup. Ten $\mathrm{ml}$ of Rhizobium culture was inoculated on to each seed. Control treatment was maintained without inoculating culture. After seed germination, only one plant was retained per pot. After 60 days of sowing, the plants were uprooted and nodule count was recorded (Tilak et al., 2006). 
Functional characterization of Rhizobial isolates

The Rhizobial isolates were subjected for functional characterization viz., IAA, GA production, ACC deaminase activity, $\mathrm{P}, \mathrm{Zn}$ and $\mathrm{Si}$ solubilization, $\mathrm{HCN}$ and siderophore production and Antagonistic activity.

\section{IAA production}

Rhizobium isolates were grown in Luria Bertani broth supplemented with $0.01 \%$ tryptophan and incubated at $28 \pm 2^{\circ} \mathrm{C}$ for 3 days under shaking condition. The broth was then centrifuged at 10,000 rpm for $20 \mathrm{~min}$ at $4^{\circ} \mathrm{C}$ to collect the supernatant. The supernatant $(2 \mathrm{ml})$ was mixed with two drops of orthophosphoric acid and $4 \mathrm{ml}$ of the Salkowski's reagent $(50 \mathrm{ml}, 35 \%$ of perchloric acid, $1 \mathrm{ml} 0.5 \mathrm{M} \mathrm{FeCl}_{3}$ solution). Development of pink colour indicates IAA production (Gordon and Paleg, 1957).

\section{GA production}

Twenty five $\mathrm{ml}$ culture supernatant of each isolate was taken in a test tube. To this, two $\mathrm{ml}$ zinc acetate was added followed by addition of two $\mathrm{ml}$ potassium ferrocyanide after two minutes. This was centrifuged at $10,000 \mathrm{rpm}$ for 15 minutes and the supernatant was collected. To $5 \mathrm{ml}$ of this supernatant, $5 \mathrm{ml}$ of 30 per cent $\mathrm{HCl}$ was added and incubated at $20^{\circ} \mathrm{C}$ for 75 mins. The blank sample was treated with $5 \mathrm{ml}$ of 30 per cent $\mathrm{HCl}$. The absorbance of the samples as well as blank was read at $254 \mathrm{~nm}$ in an UV-visible spectrophotometer. The amount of GA present in the extract was calculated from the standard curve and expressed in $\mu \mathrm{g}$ per 25 $\mathrm{ml}$ of the medium (Paleg, 1965).

\section{ACC deaminase activity}

ACC deaminase activity was determined by measuring the production of $\alpha$ - ketobutyrate and ammonia generated by the cleavage of ACC deaminase. The overnight grown bacterial cells in YEMA broth were harvested by centrifugation at $3000 \mathrm{rpm}$ for $5 \mathrm{~min}$, followed by washing twice with $0.1 \mathrm{M}$ Tris$\mathrm{HCl}(\mathrm{pH}$ 7.5). Supernatant was discarded and the pellet was resuspended in $200 \mu 1$ of 0.1 MTris-HCl ( $\mathrm{pH}$ 8.5). The cells were labilized by adding 5 per cent toluene and then vortexed at highest speed for 30 seconds. Fifty $\mu \mathrm{l}$ of labilized cell suspension was incubated with $5 \mu \mathrm{l}$ of $0.3 \mathrm{M}$ ACC in an eppendorf tube at $28^{\circ} \mathrm{C}$ for $30 \mathrm{~min}$. Fifty $\mu \mathrm{l}$ of $0.1 \mathrm{M}$ Tris- $\mathrm{HCl}(\mathrm{pH} 8.5)$ with $5 \mu \mathrm{l}$ of $0.3 \mathrm{M}$ ACC was maintained as negative control. The samples were mixed thoroughly with $500 \mu 1$ of $0.56 \mathrm{~N} \mathrm{HCl}$ by vortexing and the cell debris were removed by centrifugation at $10,000 \mathrm{rpm}$ for $5 \mathrm{~min}$. Five hundred $\mu \mathrm{l}$ aliquot of the supernatant was transferred to a glass test tube and mixed with $400 \mu \mathrm{l}$ of $0.56 \mathrm{~N}$ $\mathrm{HCl}$ and $150 \mu \mathrm{l}$ of DNF solution $(0.1 \mathrm{~g} \mathrm{2,4-}$ dinitrophenylhydrazine in $100 \mathrm{ml}$ of $2 \mathrm{~N} \mathrm{HCl}$ ) and the mixture was incubated at $28^{\circ} \mathrm{C}$ for 30 min. One $\mathrm{ml}$ of $2 \mathrm{~N} \mathrm{NaOH}$ was added to the sample before measuring the absorbance at 540 nm (Penrose and Glick, 2003).

\section{Phosphate solubilization}

Overnight grown test culture was inoculated on to Pikovskaya's media and incubated at $28 \pm 2^{\circ} \mathrm{C}$ for 5 days. Formation of zone around the colonies on Pikovskaya's medium indicates the phosphate solubilization ability of the organism. The diameter of the zone of solubilization was measured and expressed in mm (Vazquez et al., 2000).

\section{Zinc solubilization}

The Rhizobium isolates were tested for their ability to solubilize insoluble inorganic zinc on mineral salt agar medium supplemented with $\mathrm{ZnO}(0.25 \%)$. Ten $\mu \mathrm{l}$ of overnight grown culture was inoculated to mineral salt 
agar medium supplemented with $\mathrm{ZnO}(0.25$ $\%$ ) and incubated for 4 days at $28^{\circ} \mathrm{C}$. The isolate showing clear zone around the colony on the medium was considered as zinc solubilizer. The diameter of the zone of solubilization was measured and expressed in mm (Di Simine et al., 1998).

\section{Silica solubilization}

The overnight grown culture was inoculated on to silicate medium and incubated for 7 days at $28^{\circ} \mathrm{C}$ under dark conditions. Formation of zone around the bacterial colony on silicate medium indicated the silica solubilizing ability of the organism. The diameter of the zone of solubilization was measured and expressed in $\mathrm{mm}$.

\section{Siderophore production}

The Yeast extract mannitol agar was prepared using PIPES buffer (30.2 g) and Difco agar $(18.0 \mathrm{~g})$ and the $\mathrm{pH}$ was adjusted to 6.8 by addition of $0.1 \mathrm{~N} \mathrm{NaOH}$ before autoclaving (Schwyn and Neilands, 1987). After cooling, the CAS solution $(100 \mathrm{ml})$ was added along the wall of flask with gentle agitation to mix without formation of foam. The CAS agar thus prepared was poured in to the plates. After solidification, the plates were kept in the refrigerator $\left(4^{\circ} \mathrm{C}\right)$ for $24 \mathrm{~h}$. The overnight culture of isolate (10 $\mu \mathrm{l}$ each) was spotted on these CAS agar plates and incubated at $28 \pm$ $2^{\circ} \mathrm{C}$ for $48 \mathrm{~h}$. Formation of orange coloured zone around the colony was taken as positive for the siderophore production. The diameter of orange coloured zone was recorded.

\section{HCN production}

Whatman No. 1 filter paper pads were placed inside the lids of petriplates and sterilized. Yeast extract mannitol agar (YEMA) medium amended with $4.4 \mathrm{~g} / 1$ of glycine was prepared and autoclaved. Cool and molten YEMA media was added to the bottom petriplate and allowed for solidification. After solidification, $24 \mathrm{~h}$ old cultures were streaked on the solidified media. The filter paper padding inside the lid was soaked in $2 \mathrm{ml}$ sterile picric acid solution $(2.5 \mathrm{~g} / \mathrm{l}$ of picric acid and $12.5 \mathrm{~g} /$ 1 of $\left.\mathrm{Na}_{2} \mathrm{Co}_{3}\right)$. Then plates were properly sealed with parafilm in order to retain the gaseous metabolites produced by the test organism and to allow for chemical reaction with picric acid present in the filter paper padding (Wei et al., 1991). Plates were incubated at $30^{\circ} \mathrm{C}$ for 7-8 days and the colour change of filter paper was noted.

\section{In vitro screening of Rhizobium isolate against fungal pathogen (Fusarium oxysporum f. sp. udum) of pigeon pea}

The fungal pathogen was grown on potato dextrose agar plates until they completely cover the agar surface. With the help of a sterile cork borer (10 $\mathrm{mm}$ diameter), discs of fungal growth from the plates was taken and placed at the center of the fresh PDA plates. Each test isolate was then streaked parallel on either sides of the fungal disc leaving $1.5 \mathrm{~cm}$ distance from the edge of the plate. The PDA plates inoculated with only fungal pathogens were considered respective controls. The plates were incubated at $30^{\circ} \mathrm{C}$ for $96 \mathrm{~h}$. The colony diameter of the fungus in control plate and the plates streaked with Rhizobium were recorded (Sakthivel and Gnanamanickam, 1987). The zone of inhibition (ZOI) of each fungal pathogen by different isolates were calculated by using the following formula,

ZOI = Colony diameter (control plate) Colony diameter (in dual inoculated plates)

The per cent inhibition of pathogen was assessed by using the formula given below

$$
I=\frac{\mathrm{C}-\mathrm{T}}{\mathrm{C}} \times 100
$$


Morphological and characterization

The isolates were studied for morphological characteristics as per the standard procedure given by Somasegaran and Hoben (1994). The isolates were also studied for their biochemical characteristics viz., Urea hydrolysis (Lindstrom and Lehtomaki, 1988), Starch hydrolysis (De Oliverira, 2007), indole production (Kovacs, 1956), Nitrate reductase test (Costilow and Humphreys, 1955), Oxidase test (Cappuccino and Sherman, 1996), Catalase test (Graham and Parker, 1964), Citrate utilization (Simmonds, 1926).

\section{Results and Discussion}

\section{Isolation of bacteria from root nodules of pigeon pea}

Root nodules of pigeon pea were collected from different regions of northern Karnataka. Sampling details are furnished in Table 1.

Ten Rhizobium like isolates were obtained from pigeon pea root nodules. Among ten isolates, AMVPR 6, AMVPR10, AMVPR 32, AMVPR 45, AMVPR 53, AMVPR 79 and AMVPR98 were isolated from Vijayapur district, AMVPR 128, AMVPR 131 from Kalaburgi district and AMVPR178 from Bagalkot district of northern Karnataka.

\section{Assessment of nodulation}

All the isolates showed positive result for nodulation test. The Rhizobium potency in terms of formation of root nodules in pigeon pea varied from 12.00 to 14.75 number of root nodules per plant (Table 2). The results pertaining to assessment of nodulation in this study are in line with the observations made by Gouri et al., 2011, Saad et al., 2014, Demissie et al., 2018 and Degefu et al., 2018. Naeem et al., (2004) reported that four out of six strains isolated from the Medicago sativa re-nodulated the host plant confirming them as the strain of Rhizobium meliloti.

\section{Functional characterization of Rhizobium} isolates

\section{IAA production}

All the isolates were positive for IAA production and it was ranged from 16.60 to $22.85 \mu \mathrm{g}$ IAA/ $\mathrm{ml}$ of broth (Table 3 ). Highest IAA production was observed in the isolate, AMVPR $98(22.85 \mu \mathrm{g} / \mathrm{ml})$ followed by the reference strain PPM35B $(22.45 \mu \mathrm{g} / \mathrm{ml})$. The results are in line with the findings of Kucuk and Cevher (2016) who reported that the IAA production in Rhizobium isolates ranged between 15.6 to $165.6 \mu \mathrm{g} / \mathrm{ml}$. IAA production by plant growth promoting rhizobacteria (PGPR) can vary among different species and strains and it is also influenced by culture condition, growth stage and substrate availability (Mirza et al., 2001).

\section{GA production}

All the isolates were positive for GA production and it ranged from 11.00 to 14.43 $\mu \mathrm{g} / 25 \mathrm{ml}$ of broth (Table 3 ). The maximum amount GA production of $14.51 \mu \mathrm{g} / 25 \mathrm{ml}$ of broth was observed in the reference strain which was on par with the isolates AMVPR98 (14.43 $\mu \mathrm{g} / 25 \mathrm{ml}$ broth). The results of this study are in agreement with the findings of Baba et al., (2015) who reported that Rhizobium phaseoli isolated from organic farm and Kupwara district were found to produce $162 \mu \mathrm{l}$ and $153 \mu \mathrm{l}$ of GA respectively.

\section{ACC deamination activity}

All the isolates showed ACC deaminase activity and it ranged from 44.5 to 73.5 nmoles of $\alpha$-ketobutyrate $/ \mathrm{mg} / \mathrm{h}$ of broth (Table 3). The reference strain PPM35B 
reported 75.5 nmoles of $\alpha$-ketobutyrate $/ \mathrm{mg} / \mathrm{h}$ ACC deamination activity which was followed by the isolates AMVPR98 and AMVPR79 with ACC deamination activity of 73.5 and $68.5 \mathrm{nmoles}$ of $\alpha$-ketobutyrate $/ \mathrm{mg} / \mathrm{h}$ respectively. The results pertaining to ACC deaminase activity in this study are also in line with the observation made by Wenbo Ma et al., (2003) and Duan et al., (2009).

\section{P-solubilization}

P-solubilization ability of Rhizobium isolates ranged from 4.5 to $10.3 \mathrm{~mm}$. Out of ten native isolates, six isolates exhibited Psolubilization ability (Table 4). The isolate AMVPR 98 showed highest diameter of zone of solubilization $(10.3 \mathrm{~mm})$ which was followed by reference strain (PPM35B), with zone of solubilization of $9.8 \mathrm{~mm}$. Isolates of Rhizobium species differ in the ability to produce organic acids such as acetic, propionic, glycolic, formic, lactic, succinic and fumaric acid and also differ with the synthesis of phosphatase enzyme, the production of organic acids results in a decrease in $\mathrm{pH}$ and producing $\mathrm{H}^{+}$which replaces the $\mathrm{Ca}^{2+}$ and release $\mathrm{HPO}_{4}{ }^{2-}$ to the soil solution (Deubel et al., 2000).

\section{Zn solubilization}

Out of ten isolates, six isolates exhibited $\mathrm{Zn}$ solubilization ability (Table 4). The diameter of zone of zinc oxide solubilization was ranged from 9.5 to $20.5 \mathrm{~mm}$. It was highest in reference strain PPM35B $(20.5 \mathrm{~mm})$ which is followed by AMVPR98 (10.3mm).

The ability of zinc solubilization by zinc solubilizing bacteria may be due to production of organic acids in the culture medium which might have helped in the solubilization of the zinc salts (Pannerselvam et al., 2013). The solubilization of zinc by bacteria might be also due to other mechanisms which includes proton extrusion and production of chelating agents.

\section{Si solubilization}

With respect to silica solubilization, out of ten native isolates only one isolate AMVPR98 $(6.5 \mathrm{~mm})$ showed magnesium trisilicate solubilization, which is followed by reference strain PPM35B (5.5 mm) (Table 4).

Table.1 Sample details of native isolates of Rhizobia

\begin{tabular}{|c|c|c|c|c|c|c|c|}
\hline Sl. No & $\begin{array}{l}\text { Isolate } \\
\text { name }\end{array}$ & Village name & District & Type of soil & $\begin{array}{l}\text { Latitude } \\
(\mathbf{N})\end{array}$ & $\begin{array}{c}\text { Langitude } \\
\text { (E) }\end{array}$ & Elevation \\
\hline 1 & AMVPR06 & Kannur & Vijayapur & Black soil & $17^{0} 03^{\prime} 070^{\prime \prime}$ & $75^{0} 41^{\prime} 961^{\prime \prime}$ & 578 \\
\hline 2 & AMVPR10 & Mahaveer nagar & Vijayapur & Red soil & $17^{0} 01^{\prime} 087^{\prime \prime}$ & $75^{0} 14^{\prime} 048^{\prime \prime}$ & 578 \\
\hline 3 & AMVPR32 & Inchageri & Vijayapur & Red soil & $17^{0} 26^{\prime} 921^{\prime \prime}$ & $75^{0} 28^{\prime} 462^{\prime \prime}$ & 535 \\
\hline 4 & AMVPR45 & Lamana tanda & Vijayapur & Black soil & $17^{0} 32^{\prime} 399^{\prime \prime}$ & $75^{0} 38^{\prime} 183^{\prime \prime}$ & 592 \\
\hline 5 & AMVPR53 & Lamana tanda & Vijayapur & Black soil & $17^{0} 27^{\prime} 398^{\prime \prime}$ & $75^{0} 38^{\prime} 105^{\prime \prime}$ & 592 \\
\hline 6 & AMVPR79 & Hadalsang & Vijayapur & Black soil & $17^{0} 53^{\prime} 108^{\prime \prime}$ & $75^{0} 50^{\prime} 467^{\prime \prime}$ & 504 \\
\hline 7 & AMVPR98 & Hadalsang & Vijayapur & Black soil & $17^{0} 54^{\prime} 040^{\prime \prime}$ & $75^{0} 51^{\prime} 901^{\prime \prime}$ & 511 \\
\hline 8 & AMVPR128 & Alagudda & Kalaburgi & Black soil & $17^{0} 43$ "753 & $76^{0}$ '91 "643 & 491 \\
\hline 9 & AMVPR131 & Dharmapura & Kalaburgi & Black soil & $17^{0} 23$ "088 & $76^{0} 90^{\prime} " 261$ & 432 \\
\hline 10 & AMVPR179 & Sokanadagi & Bagalkot & Black soil & $16^{0} 23^{\prime} 409$ " & $75^{0} 56^{\prime} 645^{\prime \prime}$ & 528 \\
\hline
\end{tabular}


Table.2 Assessment of nodulation for native Rhizobial isolates obtained from Northern Karnataka

\begin{tabular}{|c|c|c|}
\hline Sl. No & Isolate name & Number of nodules/plant \\
\hline $\mathbf{1}$ & AMVPR06 & 12.50 \\
\hline $\mathbf{2}$ & AMVPR10 & 13.25 \\
\hline $\mathbf{3}$ & AMVPR32 & 13.75 \\
\hline $\mathbf{4}$ & AMVPR45 & 13.00 \\
\hline $\mathbf{5}$ & AMVPR53 & 14.00 \\
\hline $\mathbf{6}$ & AMVPR79 & 14.50 \\
\hline $\mathbf{7}$ & AMVPR98 & 14.75 \\
\hline $\mathbf{8}$ & AMVPR128 & 13.50 \\
\hline $\mathbf{9}$ & AMVPR131 & 13.10 \\
\hline $\mathbf{1 0}$ & AMVPR178 & 12.00 \\
\hline $\mathbf{1 1}$ & Reference & 13.25 \\
\hline & strain(PPM35B) & \\
\hline
\end{tabular}

Table.3 Quantitative estimation of growth hormones produced by native Rhizobial isolates obtained from Northern Karnataka

\begin{tabular}{|c|c|c|c|}
\hline Isolates & $\begin{array}{l}\text { IAA production } \\
(\mu \mathrm{g} / \mathrm{ml})\end{array}$ & $\begin{array}{l}\text { GA production } \\
(\mu \mathrm{g} / 25 \mathrm{ml})\end{array}$ & $\begin{array}{c}\text { ACC deaminase production } \\
\text { (nmoles of }-\alpha- \\
\text { ketobutyrate/mg/h) }\end{array}$ \\
\hline AMVPR-06 & 16.88 & 11.34 & 50.5 \\
\hline AMVPR-10 & 16.60 & 11.96 & 48.5 \\
\hline AMVPR-32 & 20.50 & 13.40 & 60.5 \\
\hline AMVPR-45 & 17.30 & 11.00 & 44.5 \\
\hline AMVPR-53 & 22.25 & 13.97 & 63.5 \\
\hline AMVPR-79 & 21.45 & 14.23 & 68.5 \\
\hline AMVPR-98 & 22.85 & 14.43 & 73.5 \\
\hline AMVPR-128 & 21.65 & 13.40 & 57.5 \\
\hline AMVPR-131 & 18.60 & 11.67 & 45.5 \\
\hline AMVPR-178 & 17.75 & 12.30 & 46.5 \\
\hline Reference strain (PPM35B) & 22.45 & 14.51 & 75.5 \\
\hline S. Em. \pm & 0.16 & 0.21 & 0.5 \\
\hline C.D@1\% & 0.503 & 0.64 & 1.57 \\
\hline
\end{tabular}


Table.4 Functional characteristics of native Rhizobial isolates obtained from Northern Karnataka

\begin{tabular}{|c|c|c|c|c|c|}
\hline Isolates & $\begin{array}{l}\text { Zone of P- solubilization } \\
\text { ( Dia in mm) \& amount } \\
\text { of Pi released }(\mu \mathrm{g} / \mathrm{ml})\end{array}$ & $\begin{array}{c}\text { Zone of Zn- } \\
\text { solubilization } \\
\text { ( Dia in } \mathbf{m m})\end{array}$ & $\begin{array}{c}\text { Zone of Si- } \\
\text { solubilization } \\
\text { (Dia in } \mathrm{mm} \text { ) }\end{array}$ & $\begin{array}{c}\mathrm{HCN} \\
\text { production }\end{array}$ & $\begin{array}{l}\text { Siderophore } \\
\text { production } \\
\text { (Dia in } \mathrm{mm} \text { ) }\end{array}$ \\
\hline AMVPR-06 & $4.5(1.14)$ & - & 0.0 & - & - \\
\hline AMVPR-10 & - & - & 0.0 & - & - \\
\hline AMVPR-32 & $7.5(1.76)$ & 10.5 & 0.0 & ++ & 8.5 \\
\hline AMVPR-45 & - & - & 0.0 & - & - \\
\hline AMVPR-53 & $8.5(2.31)$ & 11.5 & 0.0 & ++ & 9.0 \\
\hline AMVPR-79 & $8.8(2.45)$ & 12.5 & 0.0 & +++ & 9.5 \\
\hline AMVPR-98 & $10.3(3.14)$ & 16.5 & 6.5 & +++ & 10.5 \\
\hline AMVPR-128 & $5.3(1.28)$ & 9.5 & 0.0 & ++ & 6.5 \\
\hline AMVPR-131 & - & - & 0.0 & - & - \\
\hline AMVPR-178 & - & - & 0.0 & + & - \\
\hline $\begin{array}{l}\text { Reference strain } \\
\text { (PPM35B) }\end{array}$ & $9.8(2.89)$ & 20.5 & 5.5 & +++ & 10.3 \\
\hline
\end{tabular}

Note:

(-) indicates no zone of solubilisation (For P, Zn, Si solubilization)

$(-)$ indicates - No HCN production

$(+)$ indicates - Weak HCN production

$(++)$ indicates - Moderate $\mathrm{HCN}$ production

$(+++)$ indicates - Strong HCN production

Table.5 In vitro screening of Rhizobial isolates against Fusarium oxysporum f. sp. udum fungal pathogen of pigeon pea

\begin{tabular}{|c|l|c|}
\hline Sl. No & Isolates & Per cent inhibition \\
\hline $\mathbf{1}$ & AMVPR-06 & 0.00 \\
\hline $\mathbf{2}$ & AMVPR-10 & 0.00 \\
\hline $\mathbf{3}$ & AMVPR-32 & 48.75 \\
& & $(43.84)$ \\
\hline $\mathbf{4}$ & AMVPR-45 & 0.00 \\
\hline $\mathbf{5}$ & AMVPR-53 & 53.75 \\
& & $(46.68)$ \\
\hline $\mathbf{6}$ & AMVPR-79 & 68.75 \\
\hline $\mathbf{7}$ & & $(55.45)$ \\
\hline $\mathbf{8}$ & AMVPR-98 & 73.75 \\
\hline $\mathbf{9}$ & AMVPR-128 & $(58.59)$ \\
\hline $\mathbf{1 0}$ & AMVPR131 & 0.00 \\
\hline $\mathbf{1 1}$ & AMVPR178 & 0.00 \\
\hline & Reference strain (PPM35B) & 0.00 \\
\hline & & 72.5 \\
\hline & S.Em. \pm & $(57.78)$ \\
\hline & C.D @ 1\% & $\mathbf{0 . 8 9 3}$ \\
\hline
\end{tabular}

Note: Figures in parentheses indicate Arcsine transformed values Inhibition description: (0) indicates no inhibition 
Table.6 Morphological characteristics of native Rhizobial isolates of Northern Karnataka

\begin{tabular}{|c|c|c|c|c|c|c|c|}
\hline \multirow[t]{2}{*}{ Isolates } & \multicolumn{5}{|c|}{ Colony morphology } & \multicolumn{2}{|c|}{ Cell morphology } \\
\hline & Colour & Elevation & Surface & Shape & Margin & Gram reaction & Cell shape \\
\hline AMVPR-06 & Milky white & Convex & Moist & Circular & Entire & G-ve & Rod \\
\hline AMVPR-10 & Milky white & Raised & Moist & Circular & Entire & G-ve & Rod \\
\hline AMVPR-32 & Milky white & Raised & Moist & Circular & Entire & G-ve & Rod \\
\hline AMVPR-45 & Milky white & Raised & Moist & Circular & Entire & G-ve & Rod \\
\hline AMVPR-53 & Milky white & Convex & Moist & Circular & Entire & G-ve & Rod \\
\hline AMVPR-79 & Milky white & Convex & Moist & Circular & Entire & G-ve & Rod \\
\hline AMVPR-98 & Milky white & Convex & Moist & Circular & Entire & G-ve & Rod \\
\hline AMVPR-128 & Milky white & Raised & Moist & Circular & Entire & G-ve & Rod \\
\hline AMVPR-131 & Milky white & Convex & Moist & Circular & Entire & G-ve & Rod \\
\hline AMVPR-178 & Milky white & Raised & Moist & Circular & Entire & G-ve & Rod \\
\hline Reference strain (PPM35B) & Milky white & Convex & Moist & Circular & Undulated & G-ve & Rod \\
\hline
\end{tabular}

Table.7 Biochemical characteristics of native Rhizobial isolates obtained from Northern Karnataka

\begin{tabular}{|c|c|c|c|c|c|c|c|c|c|c|c|}
\hline \multirow[t]{2}{*}{ Sl. No. } & \multirow[t]{2}{*}{ Isolate No. } & \multicolumn{10}{|c|}{ Biochemical tests } \\
\hline & & $\begin{array}{c}\text { Catalase } \\
\text { Test }\end{array}$ & $\begin{array}{c}\text { Starch } \\
\text { hydrolysis }\end{array}$ & $\begin{array}{c}\text { Citrate } \\
\text { utilization }\end{array}$ & $\begin{array}{c}\text { Indole } \\
\text { production } \\
\text { test }\end{array}$ & $\begin{array}{c}\text { Methyl red } \\
\text { test }\end{array}$ & $\begin{array}{c}\text { Voges } \\
\text { proskauer } \\
\text { test }\end{array}$ & $\begin{array}{c}\text { Urease } \\
\text { test }\end{array}$ & $\begin{array}{c}\text { Nitrate } \\
\text { reduction } \\
\text { test }\end{array}$ & $\begin{array}{l}\text { Acid and gas } \\
\text { Production }\end{array}$ & Oxidase test \\
\hline & AMVPR-06 & + & - & + & - & - & - & + & - & + & + \\
\hline & AMVPR-10 & + & - & + & - & - & - & + & - & + & + \\
\hline & AMVPR-32 & + & - & + & - & - & - & + & - & + & + \\
\hline & AMVPR-45 & + & - & + & - & - & - & + & - & + & + \\
\hline & AMVPR-53 & + & - & + & - & - & - & + & - & + & + \\
\hline & AMVPR-79 & + & + & + & - & + & - & + & - & + & + \\
\hline & AMVPR-98 & + & + & + & - & + & - & + & - & + & + \\
\hline & AMVPR-128 & + & - & + & - & - & - & + & - & + & + \\
\hline & AMVPR-131 & + & - & + & - & - & - & + & - & + & + \\
\hline & AMVPR-178 & + & - & + & - & - & - & + & - & + & + \\
\hline & $\begin{array}{l}\text { Reference } \\
\text { strain(PPM35B) }\end{array}$ & + & + & + & - & + & - & + & - & + & + \\
\hline
\end{tabular}

Note:

(+) indicates positive for the test

(-) indicates negative for the test 


\section{Siderophore production}

Out of ten, five isolates were found to be positive for siderophore production. The diameter of zone of clearance on CAS agar in different isolates ranged from 6.5 to $10.5 \mathrm{~mm}$ (Table 4). Maximum diameter of zone of clearance was observed in the isolate AMVPR98 (10.5 mm). Siderophores are known to bind to the available form of iron $\left(\mathrm{Fe}^{3+}\right)$ in the chickpea rhizosphere thus making it unavailable to the phytopathogens and consequently protects the plant health (Wani and Khan, 2013).

\section{HCN production}

Out of ten isolates, six isolates, as well as reference strain were able to produce $\mathrm{HCN}$. Among six isolates, 2 isolates viz., AMVPR98 and AMVPR79 were strong (+++) $\mathrm{HCN}$ producers. The reference strain has also exhibited strong (+++) $\mathrm{HCN}$ production ability. The isolates viz., AMVPR32, AMVPR53, AMVPR128 exhibited moderate $(++)$ HCN production. The isolate AMVPR178 was weak (+) HCN producer (Table 4).

In vitro screening of Rhizobial isolates against fungal pathogen (Fusarium oxysporum f.sp. udum) of pigeon pea

With respect to In vitro screening of Rhizobium isolates against Fusarium oxysporum f.sp. udum, Out of ten isolates, four isolates exhibited potential to inhibit mycelial growth of Fusarium oxysporum $\mathrm{f}$. sp. udum (Table 5). Per cent inhibition was ranged from 48.75 to 73.75 .

The maximum per cent inhibition of 73.75 was observed in AMVPR98. These results are in close agreement with the findings of Sindhu et al., (2010) and Subhani et al., (2013) who also reported reduction of
Fusarium wilt of chickpea by Rhizobium sp. Similarly, Kucuk et al., (2013) also observed the inhibition of some Fusarium sp. due to Rhizobium strains.

\section{Characterization of the selected isolates for morphological traits}

With respect to the morphological characterization, all the ten native isolates were found to be rod shaped and showed gram negative for gram staining reaction (Table 6). All the isolates were milky white in colour, circular in shape and has moist surface. The elevations of colonies were convex in case of AMVPR06, AMVPR53, AMVPR79, AMVPR98, AMVPR131 isolates and reference strain (PPM35B). Whereas raised elevation in case of AMVPR10, AMVPR32, AMVPR45, AMVPR128 and AMVPR 178. The margins of the colonies of all the isolates were entire where as it was undulated in reference strain. Results are in concurrence with the findings of Deka and Azad (2006) who reported that cells of the isolates of Rhizobium were rod shaped, motile and Gram negative.

\section{Characterization of the selected isolates for biochemical traits}

With respect to biochemical characterization, all the isolates showed positive for citrate utilization, urease, citrate, acid and gas production and oxidase tests and negative for indole production, nitrate reduction and Voges proskauer's tests. Only two isolates, AMVPR 79 and AMVPR98 were positive for methyl red test and starch hydrolysis. Similarly, Prajapati et al., (2018) reported that Rhizobium isolates were positive for biochemical test viz., catalase test, starch hydrolysis test.

In conclusion the pigeon pea is an important legume plant widely cultivated and consumed 
in different parts of Karnataka. It is also used in co-cropping and intercropping systems for enhancing soil fertility through its symbiotic association with rhizobia. The present study revealed the presence of plant growth promoting rhizobial strains in the root nodules of pigeon pea plants growing in northern regions of Karnataka. The isolates have the ability to produce IAA, GA, HCN and siderophores, Solubilization of inorganic phosphate, Zinc oxide and magnesium trisilicate and have an antagonistic activity against pigeon pea Fusarium wilt caused by Fusarium oxyporum f. sp. udum. Hence, the isolated efficient plant growth promoting Rhizobial isolates could be used as inoculants to improve the yield of pigeon pea.

\section{References}

Ahemad, M. and Kibret, M., 2013, Mechanisms and applications of plant growth promoting rhizobacteria: Current perspective. J. King Saud. Univ., 14: 173181.

Alikhani, H. A. and Yakhchali, B., 2009, Potential of Iranian rhizobial strains as plant growth promoting rhizobacteria (PGPR) and effects of selected strains on growth characteristics of wheat, corn, and alfalfa. Desert., 14: 27-35.

Baba, Z. A., Aziz, A. Z., Sheikh, T. A., Fayaz, A., Sheikh, Z. A., Khan, B. S., Saher, B. and Hamid, B., 2015, Studies on soil health and plant growth promoting potential of Rhizobium isolates. Emirates J. of Food and Agri., 27(5): 423-429.

Bhattacharya, S. and Chandra, R., 2013, Effect of inoculation methods of Mesorhizobium ciceri and PGPR in chickpea (Cicer areietinum $\mathrm{L}$.) on symbiotic traits, yields, nutrient uptake and soil properties. Legume Res., 36: 331-37.

Cappuccino, J. G. and Sherman, N., 1996, Microbiology: A laboratory manual, The Benjamine/Comings Publishing Company, Inc., California.

Carson, K. C., Meyer, J. M. and Dilworth, M.
J., 2000, Hydroxamate siderophores of root nodule bacteria. Soil Biol. Biochem., 32: 11-21.

Costilow, R. N. And Humphreys, T. W., 1995, Nitrate reduction by certain strains of Lactobacillus plantarum. Sci., 121-168.

Chandrakala, C., Voleti, S. R., Bandeppa, S. and Sunil, N., 2019, Silicate solubil0ization and plant growth promoting potential of Rhizobium sp. isolated from rice rhizosphere. Int. J. Curr. Microbiol. App. Sci., 7(4): 543-556.

Dakora, F. D. and Kenya, S. O., 1997, Contribution of legume nitrogen fixation to sustainable agriculture in sub-Saharan Africa. Soil Biol. Biochem., 29: 809-17.

Degefu, T., Wolde-meskel, E., Adem, M., Fikre1, A., Amede, T. and Ojiewo, C., 2018, Morphophysiological diversity of rhizobia nodulating pigeon pea (Cajanus cajan L. Millsp.) growing in Ethiopia. African J. Biotec., 17(6): 167-177.

Deka, A. K. and Azad, P., 2006, Isolation of Rhizobium strains cultural and biochemical characteristics. Legume Res., 29(3): 209-212.

Demissie, N., Degefu, T., Ergena, A. and Ojiewo, C., 2018, Phenotypic characteristics of rhizobial and nonrhizobial isolates recovered from root nodules of chickpea (Cicer arietinum L.) grown in Ethiopia. African J. Microbiol. Res., 12(4): 73-85.

De Oliveira, A. N., Andrade, J. S. and Chagas, J. A. F., 2007, Rhizobia amylase production using various starchy substances as carbon substrates. Braz. J. Microbiol., 38:208-16.

Di Simine, C. D., Sayer, J. A. and Gadd, G.M., 1998, Solubilization of zinc phosphate by a strain of Pseudomonas fluorescens isolated from a forest. Soil. Biol Fertil Soils., 28: 87-94.

Deubel, A., Gransee. and Merbach, W., 2000, Transformation of organic rhizodeposits by rhizoplane bacteria and its influence on the availability of tertiary calcium phosphate. J. Plant Nutr. Soil Sci., 163: 387-392. 
Duan, J., Muller, K. M., Charles, T.C., Vesely, S. and Glick, B. R., 2009, "1Aminocyclopropane-1-carboxylate (ACC) deaminase genes in rhizobia from southern Saskatchewan." Microbial Ecology., 57(3): 423-436.

Gauri., Singh, A. K., Bhatt, R. P., Pant, S. and Kaur, M., 2011, Characterization of Rhizobium isolated from root nodules of Trifolium alexandrinum. J. Agril. Technol., 7(6): 1705-1723.

Giller, K. E., 2001, Nitrogen fixation in tropical cropping system, 2nd ed. CABI Publishing, Walling Ford, UK., 4484460.

Graham, P. H. and Parker, C. A., 1964, Diagnostic features in the characterization of the root nodule bacteria of legume. Plant and soil, 28: 383-396.

Gorden, S. A. and Paleg, L. G., 1957, Observations on the quantitative determination of indole acetic acid. Physiol.Plant., 10: 39-47.

Hemissi, I., Mabrouk, Y., Abdi, N., Bouraoui, M., Saidi, M. and Sifi, B., 2011, Effects of some Rhizobium strains on chickpea growth and biological control of Rhizoctonia solani. African J. Microbiol. Res., 4080-4090.

Kantar, F., Elkoca, E., Ogutcu, H. and Algur, O. F., 2003, Chickpea yields in relation to Rhizobium inoculation from wild chickpea at high altitudes. J. Agron. Crop Sci., 189: 291-97.

Kovacs, N., 1956, Identification of Pseudomonas pyocyanea by the oxidase reaction. Nature., 178-703.

Kucuk, C., 2013, In vitro antagonism of Rhizobium strains isolated from various legumes. J. Applied Biol. Sci., 7: 24-30.

Kucuk, C. and Cevheri, C., 2016, Indole acid production by Rhizobium sp. isolated from pea ( Pisum sativum L. ssp. arvense). Turkish Journal of Life Sciences., 1: 043-045.

Kumar Rao, J. V., Dart, P. J., Matsumoto, T. and Day, J. M., 1981, Nitrogen fixation by pigeonpea. Soil. Biol. Biochem., 16:
89-91.

Lindstrom, K. and Lehtomaki, S., 1988, Metabolic properties, maximum growth temperature and phage sensitivity of Rhizobium sp. compared with other fast growing rhizobia. FEMS Microbiol. Lett., 50: 277-287.

Mirza, M. S., Ahmad, W., Latif, F., Haurat, J., Bally, R., Normand, P. and Malik, K. A., 2001, Isolation, partial characterization, and the effect of plant growth promoting bacteria (PGPB) on micro propagated sugarcane in vitro. Pl. Soil., 237: 47-54.

Naeem, F. I., Ashraf, M. M., Malik, K. A. and Hafeez, F. Y., 2004, Competitiveness of introduced Rhizobium strains for nodulation in fodder legumes. Pak. J. Bot., 36(1): 159-166.

Oke, O. L., 1967, Nirogen fixing capacity of some Nigerian legumes. Exptl. Agric., 3: 315-321.

Osman, A. G., Rugheim, A. M. E. and Elsoni, E. M., 2011, Effects of biofertilization on nodulation, nitrogen and phosphorus content and yield of pigeon pea (Cajanus cajan). Advances in Environmental Biology., 5(9): 2742-2749.

Paleg, L., Kende, H., Ninnemann, H. and Lang, A., 1965, Physiological Effects of Gibberellic Acid. Plant Physiol., 40(1): 165-169.

Panneerselvam, P., Sarith, B., Mohanda, S., Upret, K. K., Poovarasa, S., Sulladmat, V. V. and Venugopalan, R., 2013, Isolation and characterization of zinc solubilizing bacteria from stone quarry dust powder. Biol agri and hortic., 29(2): 118-131.

Peix, A., Rivas-Boyero, A. A., Mateos, P. F. and Velazquez, E., 2001, Growth promotion of chickpea and barley by a phosphate solubilizing strain of Mesorhizobium mediterraneum under growth chamber conditions. Soil Biol. Biochem., 33: 103-110.

Penrose, D. M and Glick, B.R., 2003, Methods for isolating and characterizing $\mathrm{ACC}$ deaminase-containing plant growthpromoting rhizobacteria. Physiologia 
Plantarum., 118: 10-15.

Prajapati, S., Dadke, M. S., Surekha, S., Godika. and Krishna, V. P., 2018, Isolation and characterization of Rhizobium meliloti isolated from rhizosphere soil and roots of fenugreek from different locations. Int. J. Curr. Microbiol. App. Sci., 7(6): 1460-1467.

Richardson, A. E., 2001, Prospects for using soil microorganisms to improve the acquisition of phosphorus by plants. Aust. J. Pl. Physiol., 28: 897-906.

Saad, A. O. A., Hussam, H. A., Sami, K. M., Hassan. and Amany, M. A., 2014, Studying general characteristics and effectiveness of Rhizobium isolated from different leguminous plants. Minia J. Agric. Res and Develop., 34(1): 137-147.

Sakthivel, N. and Gnanamanickam, S. S., 1987, Evaluation of Pseudomonas fluorescens for suppression of sheath rot disease and enhancement of grain yields in rice (Oryza sativa L.). Appl. Environ. Microbiol. 47: 2056-2059.

Schwyn, B. and Neilands, J. B., 1987, Universal chemical assay for the detection and determination of siderophores. Ann. Biochem., 160: 47-56.

Simmonds, J. S. 1926. A culture medium for differentiating organisms of typhoidcolon aerogenes groups and for isolation of certain fungi. J. Infect. Dis., 39:209.

Sindhu, S. S., Dua, S., Verma, M. K. and Khandewal, A., 2010, Growth promotion of legumes by inoculation of rhizosphere bacteria. Microbes for Legume Improvement, 12: 6-9.

Subhani, M. N., Talib, S., Hussain, S., Iqbal, J. and Hussain, N., 2013, Management of chickpea wilt caused by Fusarium oxysporium f. sp. ciceris through antagonistic microorganisms. Can. J. Pl Protection., 4: 1-6.

Tilak, K. V., Ranganayaki, N., Pal, K. K. Saxena, A. K., Nautiyal, C. S., Mittal, S., Tripathi, A. K. and Johri, B. N., 2006, Diversity of plant growth and soil health supporting bacteria. Curr Sci., 89: 13650.

Vazquez, P., Holguin, G., Puente, M. E., LopezCortes, A. and Bashan, Y., 2000, Phosphate-solubilizing microorganisms associated with the rhizosphere of mangroves in a semiarid coastal lagoon. Biol. Fertil. Soils., 30: 460-468.

Wani and Khan., 2013, Isolation of multiple metal and antibiotic resistant Mesorhizobium sp. and their plant growth promoting activity. Research $J$. Microbiol., 8: 25-35.

Wei, G., Kloepper, J. W. and Tuzun, S., 1991, Induction of systemic resistance of cucumber to Colletotrichum orbiculare by selected strains of plant growth promoting rhizobacteria. Phytopathol., 81: 1508-1512.

Wenbo Ma., Frederique, C., Guinel., Bernard, R., 2003, Rhizobium leguminosarum biovar viciae, 1-Aminocyclopropane-1carboxylate deaminase promotes nodulation of pea plants. Appl. Envi. Microbiol., 69(8): 4396-4402.

Yanni, Y. G., Rizk, R. Y., Abd El-Fattah, F. K., Squartini, A., Corich, V., Giacomini, A., Bruijn, F., Rademaker, J., Maya-Flores, J. and Dazzo, F. B., 2001, The beneficial plant growth promoting association of Rhizobium legiminosarum bv. trifolli with rice roots. Aust. J. Plant Physiol., 28: $845-870$.

\section{How to cite this article:}

Harshitha, B. A., Geeta. Goudar, P. U. Krishnaraj and Koti, R. V. 2020. Characterization of Plant Growth Promoting Rhizobial Isolates for Pigeon Pea (Cajanus cajan [L.] Mill sp). Int.J.Curr.Microbiol.App.Sci. 9(07): 3776-3788. doi: https://doi.org/10.20546/ijcmas.2020.907.442 